\title{
IMPACT OF INFRASTRUCTURE ON MORTALITY IN MARGINALISED AND SEGREGATED COMMUNITIES IN THE SLOVAK REPUBLIC
}

\author{
Viliam Kováč ${ }^{1}$, Beáta Gavurová ${ }^{2}$ \\ ${ }^{1}$ Department of Finance, Faculty of Economics, Technical University of Košice, Košice, Slovak Republic \\ ${ }^{2}$ Department of Banking and Investment, Faculty of Economics, Technical University of Košice, Košice, Slovak Republic
}

\section{SUMMARY}

Aim: Poverty and social exclusion is measured through different criteria and one of them is the health sector. The relationship between Roma population and the health sector is on the edge of researchers' interest in the Slovak Republic. The purpose of this paper is a quantification of the regional disparities in the development of mortality which is causally linked with selected infrastructural determinants - namely access to water and sewerage. These determinants differently participate in the structure of mortality in marginalised and segregated communities and they deepen regional disparities in health.

Methods: It is a spatial analysis of the districts of the Slovak Republic. The data from the Atlas of Roma communities in Slovakia 2013 is applied. Through the multiple linear regression model the relationship between mortality of the Roma population and water and sewerage availability in the Roma settlements is examined. Similarity between the districts is measured by the Euclidean metric system.

Results: The most appropriate district for representing the Slovak Republic average is the Dunajská Streda district in a field of arithmetic mean and the Velký Krtîs district in a field of median value. The outermost district is represented by the Košice-okolie district, conversely, the Trnava district is the closest to the rest of the Slovak Republic. The highest statistically significant impacts on mortality are explored in public water supply extension plan and public sewerage supply extension plan. It seems that water play a greater role in determining health of Roma population. The highest number of inhabitants with supplied public water and public sewerage is kept by the Kežmarok district, the Košice district, and the Spišská Nová Ves district.

Conclusions: Our results can be beneficial for health decision making, since in the Strategic Framework for Health of the Slovak Republic metrics for measuring and evaluating health aspects in Roma communities absent and that prevents them to be correlated with the planned interventions.

Key words: mortality, Roma nationality, segregated concentrations, public water supply, public sewerage, Slovak Republic

Address for correspondence: B. Gavurová, Department of Banking and Investment, Faculty of Economics, Technical University of Košice, Němcovej 32, Košice, Slovak Republic. E-mail: beata.gavurova@tuke.sk

https://doi.org/10.21101/cejph.a4959

\section{INTRODUCTION}

The Slovak Republic is one of the countries significantly suffering from the problem of health inequalities, in particular concerning the minority groups of the population living in areas of concentrated poverty. The main process of measuring the health of the Roma communities has become a major question, as in the Slovak Republic, according to the results of available studies is an alarming trend of deteriorating state of health of the Roma population (1-4). According to the Atlas of Roma Communities in Slovakia 2013 (5), there is a population of 402,840 Roma people, making it a $7.45 \%$ share of the Slovak population - about 80,000 more than in 2004. About $46.5 \%$ of the Slovak Roma population live in the diffusion of majority population and $17 \%$ in the segregated areas, particularly in the separate settlements). From 2,890 Slovak villages the Roma community lives in 1,070 of them. There are identified 804 Roma concentrations in 584 villages, where Roma do not live in complete suspension of the majority, of which 246 concentrations are inside the village and 327 concentrations are out of the villages. The 231 segregated Roma concentrations were registered in 195 villages. In terms of the absolute numbers, most of the Roma population live in the district Košice-okolie 22,922 making it a share of $6.5 \%$ of the total number of the Roma population in the Slovak Republic. It is followed by the districts of Rimavská Sobota - 21,131, Spišská Nová Ves - 19,036, Michalovce - 17,726, Trebišov - 17,234, Kežmarok - 17,132, Prešov - 16,376, Vranov nad Toplou-14,588, Rožňava-12,978, Lučenec $-11,490$, and Sabinov - 10,696. In the 11 districts more than a half - a 51.36\% share - of the whole Roma population in the Slovak Republic live (3).

The World Health Organization uses the Dahlgren-Whitehead model to explicitly demonstrate the relationship between different determinants and health, which reflects highly on the causes of health inequalities. The top level is the general, socio-economic, cultural, and environmental conditions. Levels of health in this model do not vary randomly but they are the result of systematic differences in the distribution of factors that affects them (6). In the analysis of the health of the Roma communities, the selection 
of structural factors is significant, but also highly aggregate. It consists of living and working conditions, health-related behaviour, psychosocial factors and previous social status. Living and working conditions affect the health of residents of the settlement through direct and indirect physical and psychological mechanisms and people feel the impact of these factors for a long time. Poor conditions in childhood definitely affect health in later life. Outcome of the unfavourable factors is determined by the place where people live and also by their position in the labour market (4). Some groups of people in villages do not yet have access to drinking water, to sewerage, to affordable electricity, central heating, thermal insulation, and so on. Life in moist and densely crowded conditions, physically demanding work and other unfavourable conditions affect very negatively health of such area residents. Health behaviour which consists, for instance, of ensuring good diet, a level of physical activity, alcohol consumption, tobacco, sexual behaviour, and impacts of the socio-economic and cultural factors. This justifies the sometimes striking differences in health among social groups in the region, among the regions within countries and among the countries. This consequent fact is confirmed by the results of the research studies that declare causality between individual behaviour of people and their share in health from $25 \%$ to $35 \%(7,8)$. The large variations exist among the European countries particularly (6).

The Slovak Republic still absent any studies or analyses addressing the complex issue of health risks in the settlements, ways of their long-term monitoring and quantification of their impact on health as well as economic and social system. The available partial outcomes of the research studies of some scientific research institutions provide information only on strictly selected and analysed problem related to the research assignment $(1,3$, 9-10). Their heterogeneity, focus, diversity of research objectives, scope of action research and the type of research hypotheses are evidence of the absence of continuity in the research projects and the research teams in the context of their non-systemic solution to the complex issue of health and human health risks in settlements in the Slovak Republic. These facts gave rise to a detailed examination of the significance of individual determinants of health in the community and the possibility of regulation and implementation by targeted policies. The partial outputs of the analyses are subject of the following sections.

There is to note that the figures assigned to population living in segregated concentrations are not explored in field of nationality. It is caused by the fact the whole population in such a community is considered to have the Roma nationality. However, this cannot be based on any scientific evidence. It is absolutely true that person of no other nationality lives in these segregated concentrations. Therefore, the whole population of all these segregated concentrations is for purpose of this analysis considered to be and in fact simply is of the Roma nationality.

\section{MATERIALS AND METHODS}

The whole analysis is connected to a spatial understanding of the dataset - the districts are applied as the administrative units to determine a spatial aspect. The multiple linear regression is employed to construct the regression model. It means one explained dimension is modelled by more than one explaining dimension.
Regarding the administrative division of the Slovak districts, the Bratislava I district, the Bratislava II district, the Bratislava III district, the Bratislava IV district, and the Bratislava V district are considered to be the sole Bratislava district. Identically, the Košice I district, the Košice II district, the Košice III district, and the Košice IV district build the sole Košice district. This simplification is caused by the construction of the source dataset. Moreover, there are no available values for the Bytča district, the Námestovo district, and the Tvrdošín district, because there was no surveying during obtaining the values for the Atlas of Roma communities in Slovakia 2013 (5).

Mortality - M - in form of a number of deceased inhabitants performs as the explained variable.

The explaining variables are:

- Roma population - RP;

- segregated concentration female population - FP;

- segregated concentration male population - MP;

- segregated concentration public water supplied dwellings PWSD;

- segregated concentration public water usage dwellings PWUD;

- segregated concentration public water supply extension PWSE;

- segregated concentration public sewerage supplied dwellings - PSSD;

- segregated concentration public sewerage supply extension plan - PSSEP.

Roma population is a number of inhabitants of the Roma nationality. It is the only dimension not related to segregated concentration and not representing an attribute of the particular population concentration itself. All the other variables are assigned to the observed segregated concentrations. Segregated concentration male population is a number of male inhabitants living in the segregated concentrations, female alternation is a number of female inhabitants. The remaining five dimensions represent a quantified share of the segregated concentration population according to the findings of the Atlas of Roma communities in Slovakia 2013 (5). For each concentration the individual figure for all the variables is quantified correspondingly with a share of dwellings that are considered to fulfil requirement for the explored point. This technique is chosen because of characteristics of this data, its obtaining and very clear interpretation.

Quantification of these parameters looks like:

$$
S C V=\frac{D F R}{D N F R} S C P
$$

where the individual variables mean:

$S C V$ - the parameter assigned to the segregated concentration; $D F R$ - a number of dwellings in the segregated concentration fulfilling requirement of the parameter;

DNFR - a number of dwellings in the segregated concentration not fulfilling requirement of the parameter;

$S C P$ - a number of inhabitants of the segregated concentration.

According to this approach, the segregated concentration public water supplied dwellings variable performs as a number of inhabitants living in dwellings which can be supplied by public water. The segregated concentration public water usage dwellings variable represents a number of inhabitants living in dwellings which not only access to public water is possible 
for, but also use this access on common base. The segregated concentration public water supply extension variable embodies a number of segregated concentrations where an extension of the currently operating public water supply is being built in the present time - in the time of collecting information for the source dataset. The subsequent variable segregated concentration public sewerage supplied dwellings performs as a quantified number of inhabitants living in the dwelling with possibility of connection to public sewer. The last variable segregated concentration public sewerage supply extension plan symbolise a number of segregated concentrations where public sewerage is already available, but it is planned to be extended in the future.

All the computation methods and all the outcomes are conducted in the R software statistical environment.

\section{RESULTS AND DISCUSSION}

The impact of mentioned variables on the Roma mortality is explored with the aim to find out the correlations and significance of the factors considering infrastructure of the Roma settlements.

The regression model equation looks like:

$M=10596.55+0.65 R P-21.75 F P+20.39 M P+7.62$ $P W S D-11.89 P W U D-3765.27$ PWSE - 3.44 PSSD + 1302.05 PSSEP

Correctness of the model is based on the coefficient of determination $\mathrm{R}^{2}$ which stands at 0.30 and its adjusted version at 0.21 . Also, the F-statistics demonstrates suitability of the model construction by its value of 3.28 on 8 and 60 degrees of freedom with p-value standing at 0.004 . The $90 \%$ confidence interval is applied, because $95 \%$ way showed very close figures to the original ones, so this visualisation provides a better view of the probable values of the dimensions.

All the variables fulfil requirement to be statistically significant except for the segregated concentration public sewerage supplied dwellings variable. Its p-value only slightly oversteps a ten-percent significance level and peaks at 0.135 . The highest statistical significance of the fourth level is reached by the constant value with p-value at $<0.001$ which can be considered equal to 0 . The segregated concentration public sewerage supply extension plan variable fulfils condition for the third statistical level of significance with p-value standing at 0.008 . The second-level statistical significance is reached by the rest of the variables involved in the regression model.

The highest value is at the level of $10,596.55$ for estimated beta coefficients. The second highest impact and also the highest negative impact are assigned to the segregated concentration public water supply extension variable at level of $-3,765.27$. The lowest impact belongs to the Roma population variable whose estimated beta coefficient stands at 0.65 . The units of the independent variables are as stated in the previous section and this should be regarded in a comparison of the regressors' influence. The statistical significance of the regressors is determined by their p-values. These figures come from the computation where the t-statistics value serve as the input. There is quite markedly visible characteristic of the individual dimensions applied as the regression variables. A positive impact on the explained dimension is caused by the constant value, the Roma population variable, the segregated concentration male population variable, the segregated concentration public water supplied dwellings variable, and the segregated concentration public sewerage supply extension plan. On the other hand, a negative impact on a number of deceased inhabitants the other four variables have - the segregated concentration female population variable, the segregated concentration public water usage dwellings variable, the segregated concentration public water supply extension variable, and the segregated concentration public sewerage supplied dwellings variable. The ones pointing on the quantified number of inhabitants according to the input parameters retain lower estimated beta coefficients than the ones counting numbers of the segregated concentrations, what is understandable fact based on their source values.

To get a precise picture about a statistical informative value of the model, the tests for heteroscedasticity of the source data and multicollinearity of the explored dimensions are applied. Also, residuals are tested whether their values fulfil requirement of coming from the normal probability distribution. The significance level to determine whether p-value rejects or does not reject the zero hypothesis is set to five per cent, that is 0.05 .

Firstly, the Jarque-Bera test is conducted. The test statistics reaches value of 5.95 at 2 degrees of freedom with p-value stand-

Table 1. Regression model attributes

\begin{tabular}{|c|c|c|c|c|c|c|}
\hline \multirow{2}{*}{ Variable } & \multirow{2}{*}{$\begin{array}{l}\text { Estimated } \\
\text { coefficients }\end{array}$} & \multicolumn{2}{|c|}{$90 \%$ confidence interval } & \multirow{2}{*}{ Standard error } & \multirow{2}{*}{$p$-value } & \multirow{2}{*}{$\begin{array}{c}\text { Significance } \\
\text { level }\end{array}$} \\
\hline & & Lower boundary & Upper boundary & & & \\
\hline Constant value & $10,596.55$ & $8,864.33$ & $12,328.76$ & $1,036.85$ & $<0.001$ & $\star \star \star$ \\
\hline Roma population & 0.65 & 0.22 & 1.07 & 0.25 & 0.014 & * \\
\hline Male population & 20.39 & 5.67 & 35.10 & 8.81 & 0.024 & * \\
\hline Female population & -21.75 & -36.92 & -6.58 & 9.08 & 0.020 & * \\
\hline Public water supplied dwellings & 7.62 & 1.41 & 13.83 & 3.72 & 0.045 & * \\
\hline Public water usage dwellings & -11.89 & -20.45 & -3.32 & 5.13 & 0.024 & * \\
\hline Public water supply extension & $-3,765.27$ & $-6,808.43$ & -722.11 & $1,821.54$ & 0.043 & * \\
\hline Public sewerage supplied dwellings & -3.44 & -7.22 & 0.35 & 2.27 & 0.135 & \\
\hline Public sewerage supply extension plan & $1,302.05$ & 516.02 & $2,088.08$ & 470.49 & 0.008 & ** \\
\hline
\end{tabular}

All the variables except for the Roma population variable are assigned to the explored segregated concentrations only.

${ }^{* * *}$ denotes a significance level with $\mathrm{p}$-value lower than $0.001,{ }^{* *}$ denotes a significance level with $\mathrm{p}$-value lower than 0.01 , but higher than $0.001,{ }^{*}$ denotes a significance level with $p$-value lower than 0.05 , but higher than 0.01 . 
ing at 0.051 . It is a very close result, but the zero hypothesis is not rejected and can be accepted. This means residuals of the regression model come from the normal probability distribution.

Secondly, the Breusch-Pagan test and the Goldfeld-Quandt test are employed at the issue of heteroscedasticity. The BreuschPagan test statistics is at level of 11.10 with 8 degrees of freedom and p-value equal to 0.196 . This result does not reject the zero hypothesis saying homoscedaticity is present in the model. The Goldfeld-Quandt test statistics reaches value of 0.69 with 26 and 25 degrees of freedom respectively and p-value at level of 0.821 . The result of this test confirms the outcome of the previous one by not rejecting the zero hypothesis expressing the model homoscedasticity.

\section{Similarity of the Districts}

Similarity between the districts is measured by the Euclidean metric system. The two-dimensional version is applied to quantify likeness between each pair of the districts. Generally, the shorter distance is, the more similar districts are.

There are clearly visible the districts showing considerably high dissimilarities in relation to the rest of the Slovak Republic. The darker stripe is, the more dissimilar it is against the other districts and vice versa.

The ten most distant pairs of the districts are displayed in the subsequent Table 2.

As it is seen on the heat map in the Figure 1, the most distant pair of the districts is created by the Košice-okolie district and the Považská Bystrica district whose mutual distance is 10.77. All the ten longest distant pairs of the districts involve the Košice-okolie district. It presumes this district is the most distant from all of the rest of the Slovak Republic what is explored by the Table 3 .

The mutual distance of the district and the whole rest of the Slovak Republic is computed as arithmetic mean of all the distances between this district and each the remaining districts individually. An understandable fact is revealed by this angle of view. Although the Košice-okolie district is the farthest district, none of the remaining farthest districts create with it the mutually dissimilar pair of districts. It lies in a matter of fact that all these ten districts are physically near to the Košice-okolie district and this makes impossible to move off for them according to the explored parameters.

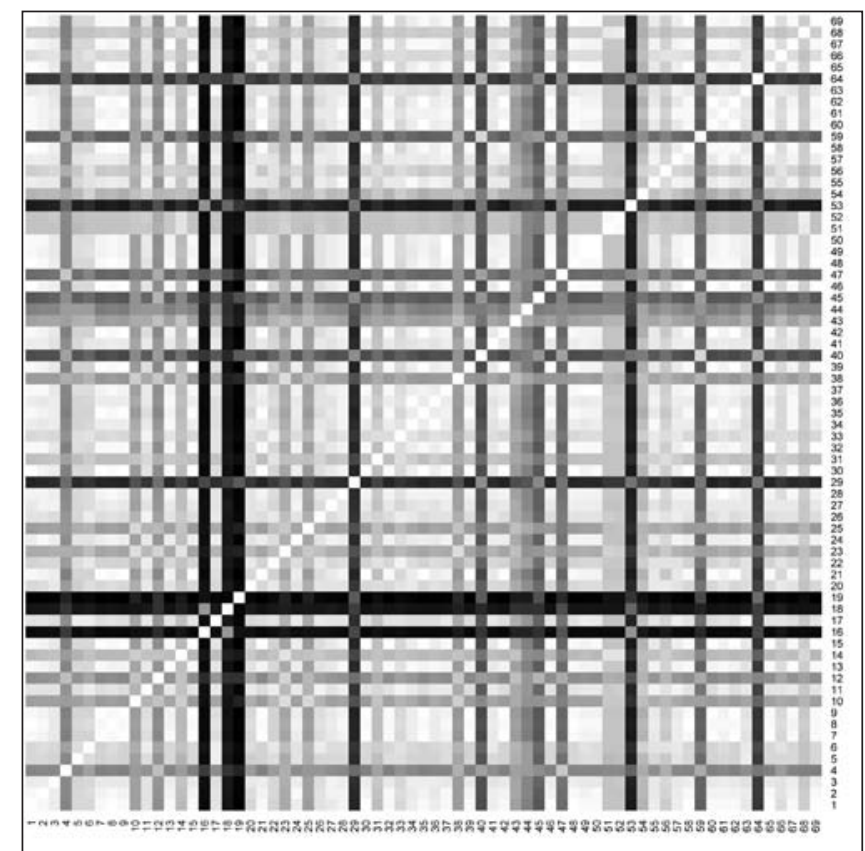

Fig. 1. Similarity heat map of the districts.

The districts in alphabetical ascending order: 1-Bánovce nad Bebravou, 2 - Banská Bystrica, 3 - Banská Štiavnica, 4 - Bardejov, 5 - Bratislava, 6 - Brezno, 7 - Čadca, 8 - Detva, 9 - Dolný Kubín, 10 - Dunajská Streda, 11 - Galanta, 12 - Gelnica, 13 Hlohovec, 14 - Humenné, 15 - llava, 16 - Kežmarok, 17 - Komárno, 18 - Košice, 19 - Košice-okolie, 20 - Krupina, 21 - Kysucké Nové Mesto, 22 - Levice, 23 - Levoča, 24 - Liptovský Mikuláš, 25 - Lučenec, 26 - Malacky, 27 - Martin, 28 - Medzilaborce, 29 - Michalovce, 30 - Myjava, 31 - Nitra, 32 - Nové Mesto nad Váhom, 33 - Nové Zámky, 34 - Partizánske, 35 - Pezinok, 36 - Piešt'any, 37 - Poltár, 38 - Poprad, 39 - Považská Bystrica, 40 - Prešov, 41 - Prievidza, 42 - Púchov, 43 - Revúca, 44 - Rimavská Sobota, 45 - Rožňava, 46 - Ružomberok, 47 - Sabinov, 48 Senec, 49 - Senica, 50 - Skalica, 51 - Snina, 52 - Sobrance, 53 - Spišská Nová Ves, 54 - Stará L'ubovňa, 55 - Stropkov, 56 - Svidník, 57 - Šal'a, 58 - Topol'čany, 59 - Trebišov, 60 - Trenčín, 61 - Trnava, 62 - Turčianske Teplice, 63 - Velký Krtíš, 64 - Vranov nad Toplou,65 - Zlaté Moravce, 66 - Zvolen, 67 - Žarnovica, 68 - Žiar nad Hronom, 69 - Žilina.

On the other hand, the ten nearest pairs of the districts are displayed in the successive Table 4.

The most similar regions are not so recognisable on the heat map in the Figure 1 than the most dissimilar are. It is caused by the fact the differences between these pairs of the regions are much smaller than it is in the previous case of the most dissimilar ones. The absolutely most similar pair of districts is formed by

Table 2. The ten longest distances between the districts

\begin{tabular}{|l|c|c|c|}
\hline Rank & District & District & Mutual distance \\
\hline 1 & Košice-okolie & Považská Bystrica & 10.77 \\
\hline 2 & Košice-okolie & Turčianske Teplice & 10.77 \\
\hline 3 & Košice-okolie & Púchov & 10.77 \\
\hline 4 & Košice-okolie & Trenčín & 10.77 \\
\hline 5 & Dolný Kubín & Košice-okolie & 10.76 \\
\hline 6 & Čadca & Košice-okolie & 10.76 \\
\hline 7 & Košice-okolie & Pezinok & 10.74 \\
\hline 8 & Košice-okolie & Kysucké Nové Mesto & 10.73 \\
\hline 9 & Ilava & Košice-okolie & 10.71 \\
\hline 10 & Košice-okolie & Myjava & \\
\hline
\end{tabular}


Table 3. The ten most distant districts to the rest of the Slovak Republic

\begin{tabular}{|l|c|c|}
\hline Rank & District & Distance \\
\hline 1 & Košice-okolie & 9.59 \\
\hline 2 & Kežmarok & 8.97 \\
\hline 3 & Košice & 8.49 \\
\hline 4 & Spišská Nová Ves & 7.55 \\
\hline 5 & Michalovce & 6.91 \\
\hline 6 & Vranov nad Toplou & 6.14 \\
\hline 7 & Prešov & 5.25 \\
\hline 8 & Rožňava & 4.90 \\
\hline 9 & Trebišov & 4.58 \\
\hline 10 & Sabinov & 4.40 \\
\hline
\end{tabular}

the Považská Bystrica district and the Turčianske Teplice district whose mutual distance reaches value of 0.0022 . The first four pairs create an own cluster evidently. The Považská Bystrica district, the Púchov district, the Trenčín district, and the Turčianske Teplice district arrange a group of the districts with very similar values of the explored parameters - the most similar ones across the whole Slovak Republic. Therefore, the outcome of the ten nearest districts to the rest of the Slovak Republic as seen in Table 5 involves the other districts than the previous table.

As it is stated above, the mutual differences between the calculated distances are very small and move on the order of tenths to hundredths. The most similar district to the rest of the Slovak Republic is the Trnava district that is only 1.90 distant from the whole Slovak Republic excluding itself.

To provide complete information about similarity of all the districts of the Slovak Republic, arithmetic mean of all the values assigned to the individual regions is computed. It reaches value of 2.87. The most similar district to this arithmetic mean is the Dunajská Streda district that is only 0.19 far away. If we have a look at the median district, we find out the Vel'ký Krtíš district is numerically the centremost with its distance of 2.03 to the rest of the Slovak Republic.

Table 4. The ten shortest distances between the districts
\begin{tabular}{|l|c|c|c|}
\hline Rank & District & District & Mutual distance \\
\hline 1 & Považská Bystrica & Turčianske Teplice & 0.0022 \\
\hline 2 & Považská Bystrica & Púchov & 0.0045 \\
\hline 3 & Púchov & Trenčín & 0.0061 \\
\hline 4 & Trenčín & Turčianske Teplice & 0.0084 \\
\hline 5 & Bánovce nad Bebravou & Topolčany & 0.0094 \\
\hline 6 & Považská Bystrica & Trenčín & 0.0106 \\
\hline 7 & Dolný Kubín & Trenčín & 0.0164 \\
\hline 8 & Kysucké Nové Mesto & Pezinok & 0.0195 \\
\hline 9 & Bánovce nad Bebravou & Senec & 0.0199 \\
\hline 10 & Dolný Kubín & Púchov & 0.0226 \\
\hline
\end{tabular}




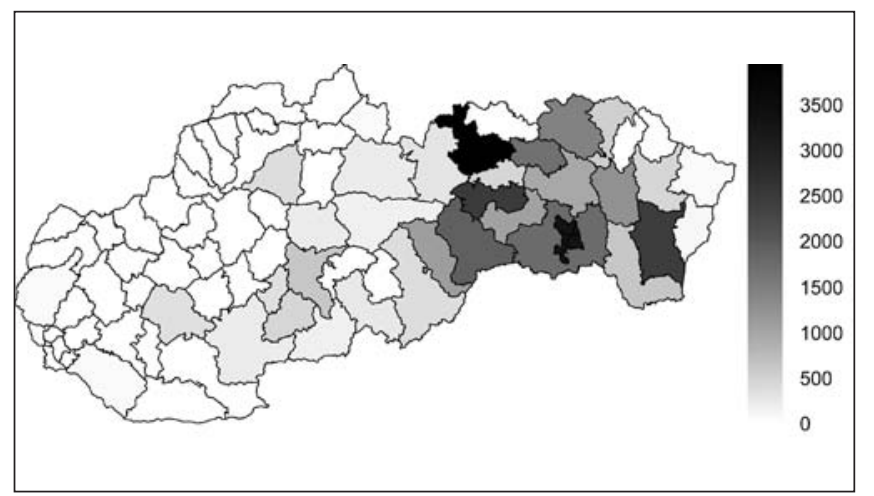

Fig. 3. Segregated concentration of public water usage dwellings according to the districts of the Slovak Republic.

The highest number of quantified inhabitants of the public water supplied dwellings is localised in the Kežmarok district, where it reaches value of 8,054.2. Successively, the Košice district follows with 6,732 quantified inhabitants and the Spišská Nová Ves district with quantified 4,696.75 inhabitants as seen on Figure 2.

In a case of the dwellings really using public water connection, decisive position is taken by the same districts as in the previous case. There are 3,942.79 quantified inhabitants using public water the Kežmarok district, 3,366 inhabitants in the Košice district, and 2,544.35 inhabitants in the Spišská Nová Ves district as seen on Figure 3.

In general, there are only 21 municipalities in the Slovak Republic where public water supply is being extended right now. Four of them are located in the Košice-okolie district, two of them in the Rožňava district and in the Vranov nad Topl'ou district. The other thirteen coloured districts involve only one municipality where an activity with public water supply is occurring - they are the Dunajská Streda district, the Gelnica district, the Humenné district, the Levoča district, the Lučenec district, the Michalovce district, the Poprad district, the Prešov district, the Revúca district, the Snina district, the Sobrance district, the Trebišov district, and the Žiar nad Hronom district as seen on Figure 4.

In a case of the public sewerage supplied dwellings, the first three districts with the highest numbers of quantified inhabitants are the same, although ordered in another way. The Košice district takes the first position with population of 6,732, the Kežmarok district follows with population of 4,699.8 and the Spišská Nová Ves district with population of 3,687.75. There is clearly visible

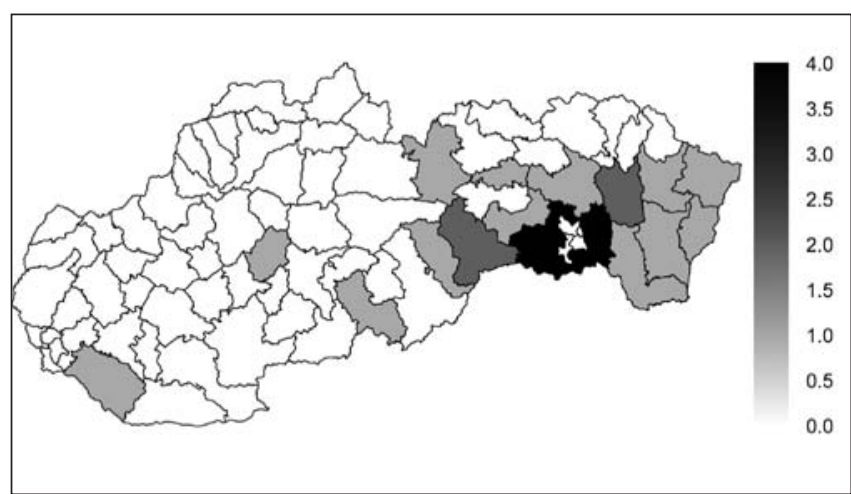

Fig. 4. Segregated concentration of public water supply extension according to the districts of the Slovak Republic.

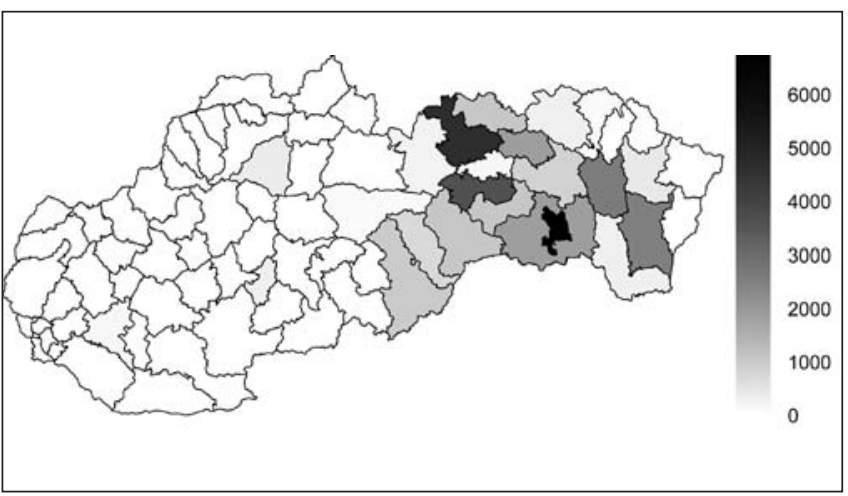

Fig. 5. Segregated concentration of public sewerage supplied dwellings according to the districts of the Slovak Republic.

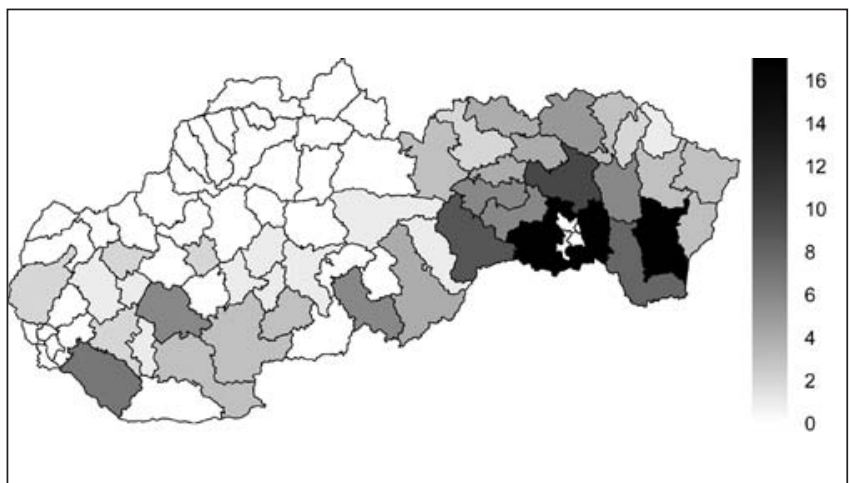

Fig. 6. Segregated concentration of public sewerage supply extension plan according to the districts of the Slovak Republic.

the same number in the Košice district as it is stated in a field of quantified inhabitants that are supplied with public water as seen on Figure 5.

In future, there are plans to extend public sewerage supply in 165 municipalities across the Slovak Republic. The most of them are situated in the Košice-okolie district and in the Michalovce district where 17 municipalities have such plans. On the third place the Prešov district stays with 10 municipalities with very small offset against the following districts as seen on Figure 6.

\section{CONCLUSIONS}

In the recent decades, the European Union constantly appeals to the urgency of addressing the issues aimed at alleviating health inequalities. The issue is too complicated and the current situation in it tells about a number of the system failures. And the numerous European Union programmes appeal to the necessity of solving the problems to mitigate the disparities in health. The locations of the segregated and marginalised settlements bear part of serious health epidemics and thus, they become complementary threat to the majority of a society. The existing governmental projects - completed and realistic - draw the attention for several years primarily on the component of education of the Roma population like a significant element in the process of eliminating the existing social problems of the Roma settlements with the contingency of the social sector and the health care sector remained completely neglected. Although there are the evident relations between the 
education and training with prospective employment, the related income and the subsequent impacts on health, the Roma settlements are currently exposed to high health risks quantifiable social causes and this causality need to be recorded and analysed. A separate analysis of the factors determining the health does not only provide relevant information on all the causal sessions, but primarily it causes a high risk of false and misleading interpretations. The focus of the analysis is laid on the examination of the impact of the selected infrastructure factors on mortality of the population of the marginalised and segregated communities with the ambition of creating a comprehensive platform for setting targeted policies to improve health.

To conclude, it is possible to state that the outcome of this analysis confirms association between an infrastructure level of the areas with a high share of population of the Roma nationality and overall mortality in the Slovak Republic.

The conducted regression analysis with mortality of the Slovak Republic population in a role of the explained dimension determines the eight subsequent factors with significant influence on the observed variable. They can be divided into two groups - demographic aspects are represented by the Roma population variable, the male population variable and the female population variable, whilst an infrastructure level is characterised by the public water supplied dwellings variable, the public water usage dwellings variable, the public water supply extension variable, and the public sewerage supply extension plan variable.

The most appropriate district to represent the Slovak Republic average is the Dunajská Streda district in a field of arithmetic mean and the Vel'ký Krtíš district in a field of median value. The most dissimilar pair of the districts consists of the Košice-okolie district and the Považská Bystrica district. On the other hand, the most similar districts are the Považská Bystrica district and the Turčianske Teplice district. It is remarkable that the Považská Bystrica district is involved in the both cases. The outermost district is represented by the Košice-okolie district. It is confirmed by its participation in the ten most distant pairs of the districts. The opposite side is held by the Trnava district which is the most near to the rest of the Slovak Republic followed very tightly by the further districts.

The crucial position among the districts with a highest quantified number of inhabitants with supplied public water and public sewerage is kept by the Kežmarok district, the Košice district, and the Spišská Nová Ves district. The other districts possess mild figures in comparison with the Slovak Republic average or are significantly below average.

The partial results of the analysis of mortality in the analysed regions characterised by high concentration of Roma populations provide a valuable platform for the examination and comparison of the mortality rates in the Roma community compared to mortality in the majority society, and provide the opportunities for the active proposals of the tools and the policies to address the issue. Without a proper understanding of the complexity of these socio-economic phenomena and their interactions in the healthcare system and the social system of the Slovak Republic, these serious and the still graduated problems of our society cannot be systematically and efficiently addressed.

\section{Acknowledgements}

This work is created within the project supported by the Scientific Grant Agency of the Ministry of Education, Science, Research and Sport of the Slovak Republic and the Slovak Academy of Sciences 1/0945/17 Economic research on quantification of marketing processes aimed at improving value for patient, multidimensional analyses of the marketing mix of healthcare facilities and quantification of their importance in the process of establishment of the system to measure the quality and efficiency in healthcare of the Slovak Republic.

\section{Conflict of Interests}

None declared

\section{REFERENCES}

1. Popper M, Szeghy P, Šarkozy Š. Roma population and health: analysis of the situation in Slovakia. Bratislava: Partners for Democratic Change Slovakia; 2009. (In Slovak.)

2. Hubková B, Tkáčiková S, Guzy J, Mareková M; HEPA-META team. Health of Roma in eastern Slovakia. Individ Soc [Internet]. 2014 [cited 2017 Dec 10];17(1):98-102. Available from: http://www.clovekaspolocnost.sk/jquery/pdf.php?gui=BPVUP9LH4QFFAACQ3Y7F2TWLK. (In Slovak.)

3. Matlovičová K, Matlovič R, Mušinka A, Židová A. The Roma population in Slovakia - basic characteristics of the Roma population with emphasis on the spatial aspects of its differentiation. In: Penczes J, Radics Z, editors. Roma population on the peripheries of the visegrad countries - spatial trends and social challenges. Debrecen; 2012. p. 77-104. (In Slovak.)

4. Mušinka A, Kolesárová J. Situation of the Roma in Slovakia and their status in the contemporary Slovak society - brief outline of the Roma situation and of associated problems. Cent Eur Reg Policy Hum Geograph. 2012;2(2):7-14.

5. Mušinka A, Škobla D, Hurrle J, Matlovičová K, Kling J. Atlas of Roma communities in Slovakia 2013. Bratislava: United Nations Regional Centre for Europe and the Commonwealth of Independent States in Bratislava - United Nations Development Programme; 2013. (In Slovak.)

6. European Commission. Reducing health inequalities in the European Union. Luxembourg: Office for Official Publications of the European Communities; 2010.

7. Carvajal S. Stress and sociocultural factors related to health status among US-Mexico border farmworkers. J Immigr Minor Health. 2014;16(6):1176-84.

8. Milner A, LaMontagne AD, Aitken Z, Bentley R, Kavanagh AM. Employment status and mental health among persons with and without a disability: evidence from an Australian cohort study. J Epidemiol Community Health. 2014;68(11):1064-71.

9. Škobla D. Survey of living conditions of Roma households in 2010. Bratislava: United Nations Development Programme; 2010. (In Slovak.)

10. Lajčáková J. Report of civil society on the implementation strategy of the Slovak Republic for Roma integration in 2020 and the revised Action Plan for the Decade in Slovakia. Budapest: Decade of Roma Inclusion Secretariat Foundation; 2013. (In Slovak.) 